Australian Journal of

Crop Science

AJCS

AJCS 13(06):828-836 (2019)

ISSN:1835-2707

doi: 10.21475/ajcs.19.13.06.p1326

\title{
Environmental variables contributing to differential performance of tropical maize hybrids across heat stress environments in South Asia
}

\author{
Vinayan MT ${ }^{1}$, PH Zaidi ${ }^{1}$, K. Seetharam ${ }^{1}$, Md. Ashraful Alam ${ }^{1}$, Salahuddin Ahmed ${ }^{2}$, KB Koirala $^{3}$, Md.Arshad ${ }^{4}$, \\ Prakash Kuchanur ${ }^{5}$, Ayyanagouda Patil ${ }^{5}$ and Shyam S. Mandal ${ }^{6}$
}

${ }^{1}$ International Maize and Wheat Improvement Center, Patancheru-502324, Hyderabad, India

${ }^{2}$ Bangladesh Agricultural Research Institute, Bangladesh

${ }^{3}$ National Maize Research Program, Rampur, Nepal

${ }^{4}$ Maize and Millets Research Institute, Sahiwal, Pakistan

${ }^{5}$ University of Agricultural Sciences Raichur, Karnataka, India

${ }^{6}$ Bihar Agricultural University, Bhagalpur, Sabour, Bihar, India

*Corresponding author: m.vinayan@cgiar.org

\begin{abstract}
Heat stress resilience in maize hybrids is emerging as an important trait in germplasm targeted for cultivation in the post-rainy season spring in South Asia. One of the major challenges in targeted breeding for these agro-ecologies is the differential response of maize genotypes to heat stress across locations during the spring season. This study is targeted at identifying the major environmental variables that contributed to the genotype $x$ environmental (GEI) yield variations observed among genotypes grown in response to heat stress. The trial dataset used for this study constitutes 46 trials $\times$ location combinations spread over a period of three years (20132015). Partial least square (PLS) regression analysis was implemented to decipher the important environmental variables contributing to the observed yield variation among maize trials planted during spring across locations of South Asia. The first two factors from the PLS study explained the 30 per cent yield variation across trials. The largest contributor of this variation was relative humidity (RH) and vapor pressure deficit (VPD) during flowering stage of the crop across the years.
\end{abstract}

Keywords: Maize; Partial Least Square, Heat Stress, Relative Humidity; Vapor Pressure Deficit.

Abbreviations: PLS, GEI, RH, VPD, $T_{\max }, T_{\min }$,

Introduction

Demand for maize in South Asia is increasing substantially due to an array of factors, such as changing diets and better remuneration from the rapidly progressing poultry sector. However, average maize yields in this region [estimated at about 2.9 tons per hectare ( $\mathrm{t} / \mathrm{ha}$ )], are still dismal and account for only about half of the world's average maize yields (FAO, 2016). Increasing productivity or production area through the deployment of improved cultivars adapted to a wider range of environments/seasons could greatly help in bridging the gap between production and demand. The maize growing season in tropical parts of South Asia is largely confined to the rainy season in South Asia, during which optimum growing conditions and abundant water sources due to rains assures a good crop. Of late, post-rainy spring season (February-May) maize is emerging as a potential segment to expand maize production, provided a few production barriers are overcome. The need for frequent irrigation and high temperature $\left(T_{\max }\right.$ $>35^{\circ} \mathrm{C}$ ) for long durations of the crop cycle (vegetative stage until early grain filling) referred to as heat stress, are the two major limiting factors of spring season maize production (FebMay) across tropical South Asia. Thus, resilience to heat stress is one of the most sought after traits in tropical germplasm targeted for maize growing zones in the spring (Zaidi and Cairns, 2011). Largely characterized by high temperatures $\left(T_{\max }\right.$ $>35^{\circ} \mathrm{C}$ during most of the crop cycle) during the spring season, these zones however vary with respect to minimum temperature $\left(T_{\min }\right)$, relative humidity $(\mathrm{RH})$ and vapor pressure deficit (VPD). These variations can often lead to differential responses in cultivar yield, representing in part or full the genotype $\times$ environment interaction (GEI) component (Vargas et al. 2007; Hu and Buyanovsky, 2003). A large and significant interaction component can upset the selection process in breeding programs and could pose a major roadblock to realizing potential gains (Westcott, 1986). Most of the statistical tools available to address $G \times E$ interaction and identify stable genotypes are limited by the scope to include 
environmental variables into their statistical models (Vargas et al. 1998).

Environmental data is easy to access. However, delineating and understanding the most important environmental variables contributing to the genotype response is essential for a successful breeding program. Identifying environmental variables influencing grain yield response in genotypes could have major implications on crop breeding and also help in environmental demarcation for targeted deployment of cultivars. Studies have reported the use of different regression and non-regression approaches in quantifying genotype response to environmental variables (Lobell et al. 2011; Huang et al. 2004); however, each has its own limitations. The Partial Least Square (PLS) method was identified as a superior analytical tool to understanding GEI (Tobias, 2003). It has been identified as extremely valuable in studies with a large number of correlated variables (Vargas et al. 2007). Though popularly used in chemometric studies, over the years, PLS' superiority over other multiple regressions approaches has been well demonstrated in different crops for various traits (Vargas et al. 1998; 2001; 2006; 2007; Fassio and Cozzolino, 2003; Hansen and Schjoerring, 2003; Ehsani et al. 1999; Talbot and Wheelwright, 1989). While PLS is not a strong model to determine cause and effect relationships, it could be an effective tool in determining important factors that contribute to the GXE component (Vargas et al. 2007). With this perspective, the current study was initiated to understand within-season climatic variations in relation to yield differences observed among germplasm characterized for heat stress tolerance over a period of three years across different locations of South Asia.

\section{Results}

\section{Grain yield under heat stress (HS)}

The study constituted 11 spring season yield trial dataset evaluated across locations of South Asia (Table 1, Figure 1). Each trial dataset comprised of different stages of maize breeding germplasm (early generation test-crosses to advance stage hybrids) evaluated at 3-5 locations under natural heat stress. The descriptive statistics of these trial data set are detailed in Table 2. In general, mean yield was low (2.64 to 4.46 ton/ha) for all the trials. Substantial differences were noted within trial yields across locations, with significant genotype $\times$ environment effect. Across-location heritability of these trials for grain yield ranged between 0.22 and 0.60 , with the exception of the year 2015 involving temperate $\times$ tropical top cross $\left(h^{2}=0.00\right)$ (Table 2$)$. While single location heritability for grain yield of this trial was acceptable (0.23 to 0.89 ), the dismal across-season heritability estimate suggests a stronger crossover performance of germplasm involved (temperate) across the locations (tropical) tested.

\section{Environmental variables}

To further explain the genotype $\times$ environment interactions, environmental variables (Temperature, Humidity and vapor pressure deficit) recorded daily were averaged across fortnightly intervals (designated Q1 to Q7) from the date of planting of the trial (Table 3). These fortnights represented three major crop growth stages (i) Q1 to Q3 [1 day after sowing (DAS) to $42 \mathrm{DAS}$ ] representing the vegetative growth phase; (ii) Q4 to Q6 (43 DAS to 84 DAS) representing the reproductive or flowering phase; and (iii) Q7 representing the early grain filling phase.

Temperature regime recorded across test locations and years during the trialing season did not vary substantially. The average daily $T_{\max }$ recorded across locations throughout the crop stages (Q1-Q7) was high $\left(>32^{\circ} \mathrm{C}\right)$. The highest $\mathrm{T}_{\max }\left(>35^{\circ} \mathrm{C}\right)$ recorded across most trial locations coincided with the reproductive stage of the crop (Q4-Q6), representing the male flowering (anthesis) period (Figure 2). The average daily night temperature $\left(T_{\min }\right)$ during the flowering stages of the crop (Q4Q6) was close to $25^{\circ} \mathrm{C}$ across locations over the three years (Table 3). The lowest $T_{\min }\left(<20^{\circ} \mathrm{C}\right)$ was recorded in a few locations of India (Sabour and Ludhiana, 2013), Pakistan (Yousafwala and Faisalabad, 2014) and Nepal (Nepalgunj, 2013 and 2015), particularly during the early growth phase (Q1).

The average relative humidity and vapor pressure deficit among the test locations were highly variable (Figure 3 ) and the locations could be clearly grouped as dry and humid. Among the five locations of the 2013 trialing season, Nepalgunj (in Nepal) and Sabour (in India) were relatively more humid and recorded low vapor pressure deficits. In 2014, except for two locations in Bangladesh (Ishurdhi and Jessore) and one in India (Raichur), all the locations were dry and recorded high vapor pressure deficit. The highest vapor pressure deficit in the 2014 trialing season was recorded at Aurangabad and Bejjanki (5.0 to $7.0 \mathrm{kPa}$ ) locations of India, particularly during the flowering stage (Q5-Q6). All the four locations in the 2015 dataset recorded low RH and high VPD, except $\mathrm{B}^{\prime}$ gudi (in India) during the last two fortnights ( $\mathrm{RH}-70 \%$ and VPD-1.8 $\mathrm{KPa}$ ).

\section{Grain yield and partial least square}

A partial least square analysis was performed using grain yield data as a dependent variable across locations to explain the influence of various environmental variables averaged over fortnightly intervals (Q1-Q7) during the trialing season. The first two latent factors extracted across 11 experimental trials evaluated over a span of three years (2013-2015) explained a cumulative 30 per cent of the variation observed among entries in the trials (Table 4). Relative ranks for each of the weather variable components as determined from the $\mathrm{X}$ loading values are presented in Table 5 .

The X-loading values from the 2013 trialing season (Table 5) indicated $T_{\min }$ during the vegetative stage (Q3) and early grain filling (Q7) followed by VPD (Q4) and RH (Q5) during the reproductive stage of crop growth as the most important variables. PLS results from the 2014 trialing season also indicated $\mathrm{RH}$ and VPD during the reproductive stage (Q5-Q6) as being the major determinants of differential grain yield response. Results of the 2015 trials showed $T_{\max }$ and VPD during the vegetative crop growth stage (Q1), RH and VPD during the flowering stage (Q4) as the most important variables contributing to the observed variation due to $\mathrm{G} \times \mathrm{E}$ 
Table 1. Description of the trial $\times$ location combinations, post-rainy spring cropping season, 2013-2015.

\begin{tabular}{|c|c|c|c|c|c|c|c|c|c|c|c|c|c|c|}
\hline \multirow{2}{*}{ Country } & \multirow{2}{*}{ Location/Trial } & \multirow{2}{*}{$\begin{array}{l}\text { Latitude \& } \\
\text { Longitude }\end{array}$} & \multirow{2}{*}{$\begin{array}{l}\text { Altitude } \\
\text { MASL }\end{array}$} & \multicolumn{3}{|c|}{2013} & \multicolumn{6}{|c|}{2014} & \multicolumn{2}{|c|}{2015} \\
\hline & & & & HTMAHT-1 & HTMAHT-2 & HSHT-1 & ABHSHT & EWATC-1 & EWATC-2 & EYATC-2 & EYBTC-1 & EYBTC-2 & ATTC-2 & $\mathrm{AS} 2 \mathrm{BH}-4$ \\
\hline \multirow[t]{7}{*}{ India } & Sabour & $25.23 \mathrm{~N} ; 87.06 \mathrm{E}$ & 43 & $\checkmark$ & $\checkmark$ & $\checkmark$ & & & & & & & & \\
\hline & B'gudi & $16.73 N ; 76.79 E$ & 446 & $*$ & $*$ & $*$ & $*$ & $\checkmark$ & $\checkmark$ & & & & $\checkmark$ & $\checkmark$ \\
\hline & Ludhiana & $30.99 N ; 75.74 \mathrm{E}$ & 233 & $\checkmark$ & $\checkmark$ & $\checkmark$ & $*$ & $*$ & $*$ & & & & & \\
\hline & Raichur & $16.22 \mathrm{~N} ; 77.38 \mathrm{E}$ & 391 & $\checkmark$ & $\checkmark$ & $\checkmark$ & $*$ & $\checkmark$ & $*$ & $\checkmark$ & $*$ & $*$ & $\checkmark$ & $\checkmark$ \\
\hline & Bejjanki & $18.25 \mathrm{~N} ; 79.02 \mathrm{E}$ & 332 & & & & $\checkmark$ & $\checkmark$ & $\checkmark$ & $\checkmark$ & $\checkmark$ & $*$ & $*$ & \\
\hline & Hyderabad & $17.51 \mathrm{~N} ; 78.27 \mathrm{E}$ & 552 & $*$ & $*$ & $\checkmark$ & $\checkmark$ & $\checkmark$ & $\checkmark$ & $*$ & $*$ & $\checkmark$ & $\checkmark$ & $\checkmark$ \\
\hline & Aurangabad & $19.69 N ; 75.08 \mathrm{E}$ & 484 & & & & & & & $*$ & $*$ & $\checkmark$ & & \\
\hline Nepal & Nepalgunj & $28.11 \mathrm{~N} ; 81.59 \mathrm{E}$ & 150 & $\checkmark$ & $\checkmark$ & $\checkmark$ & & $*$ & $*$ & $*$ & $*$ & $*$ & $\checkmark$ & $\checkmark$ \\
\hline \multirow[t]{2}{*}{ Pakistan } & Faisalabad & $31.40 \mathrm{~N} ; 73.04 \mathrm{E}$ & 192 & & & & $*$ & $\checkmark$ & $\checkmark$ & $*$ & $*$ & $*$ & & \\
\hline & Yusafwala & $30.68 N ; 73.20 E$ & 173 & & & & $\checkmark$ & $*$ & $*$ & $*$ & $\checkmark$ & $\checkmark$ & & \\
\hline \multirow[t]{2}{*}{ Bangladesh } & Jessore & $23.18 \mathrm{~N} ; 89.18 \mathrm{E}$ & 11 & & & & $\checkmark$ & $\checkmark$ & $\checkmark$ & & & & & \\
\hline & Ishurdi & $24.12 N ; 89.07 E$ & 18 & & & & $*$ & & & $\checkmark$ & $\checkmark$ & $\checkmark$ & & \\
\hline
\end{tabular}

* Locations with heritability $\leq 0.15$ and discarded from this study.

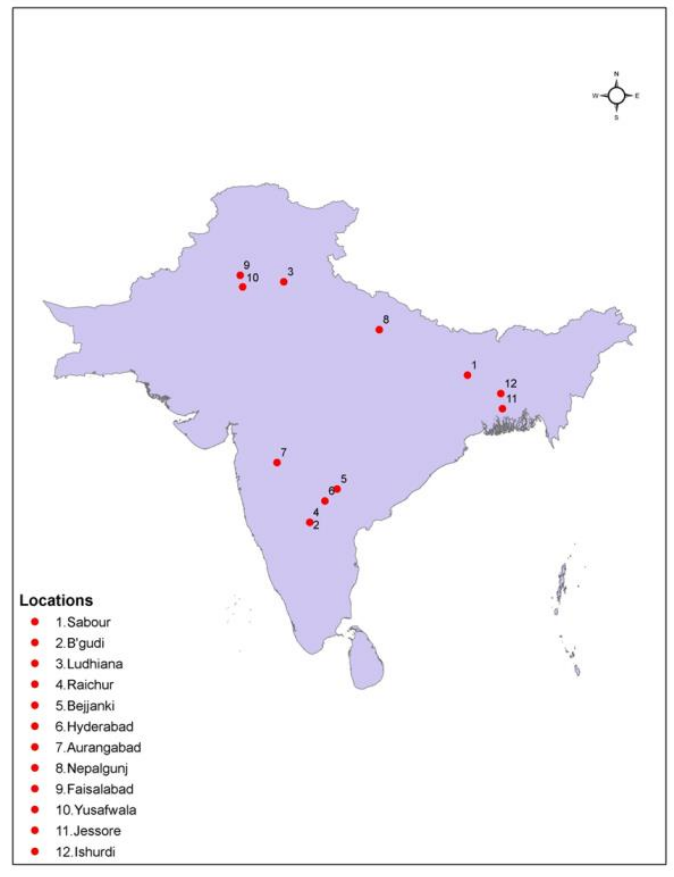

Fig 1. Location map in South and South Asia where the spring trials were evaluated 
Table 2. Grain yield performance of maize germplasm across different locations and trials across three years.

\begin{tabular}{|c|c|c|c|c|c|c|c|c|c|c|}
\hline \multirow[t]{2}{*}{ Year } & \multirow[t]{2}{*}{ Trial } & \multirow[t]{2}{*}{ Entries } & \multirow[t]{2}{*}{ Locations } & \multicolumn{3}{|c|}{ Grain Yield (ton/Ha) } & \multirow[t]{2}{*}{ Genotypic variance } & \multirow[t]{2}{*}{$\mathrm{G} \times \mathrm{E}$ variance } & \multirow{2}{*}{$\begin{array}{l}\text { Across-season } \\
\text { heritability }\end{array}$} & \multirow{2}{*}{$\begin{array}{l}\text { Single-season } \\
\text { heritability }\end{array}$} \\
\hline & & & & Mean & & & & & & \\
\hline \multirow[t]{3}{*}{2013} & НTMАНТ-1 & 300 & 4 & 3.82 & 2.24 & -5.05 & $0.34 * *$ & $0.24 * *$ & 0.60 & $0.29-0.58$ \\
\hline & НTMАНТ-2 & 300 & 4 & 3.22 & 2.48 & -4.04 & $0.15^{* *}$ & $0.28 * *$ & 0.42 & $0.32-0.51$ \\
\hline & HSHT-1 & 155 & 5 & 3.23 & 2.09 & -3.97 & $0.18 * * * *$ & $0.38 * * * *$ & 0.50 & $0.46-0.62$ \\
\hline \multirow[t]{6}{*}{2014} & ABHSHT & 20 & 4 & 4.37 & 3.69 & -5.02 & $0.30^{*}$ & $0.91 * * * *$ & 0.51 & $0.55-0.95$ \\
\hline & EWATC-1 & 145 & 6 & 3.89 & 3.26 & -4.44 & $0.12 * * * *$ & $0.24 * * *$ & 0.42 & $0.20-0.41$ \\
\hline & EWATC-2 & 140 & 5 & 4.17 & 3.74 & -4.80 & $0.10 * *$ & $0.26 * * *$ & 0.35 & $0.20-0.45$ \\
\hline & EYATC-2 & 240 & 3 & 3.31 & 3.00 & -4.04 & $0.08^{*}$ & $0.21 * *$ & 0.22 & $0.18-0.50$ \\
\hline & EYBTC-1 & 205 & 3 & 4.46 & 3.81 & -4.81 & $0.11^{*}$ & $0.25 * * *$ & 0.26 & $0.28-0.48$ \\
\hline & EYBTC-2 & 205 & 4 & 4.30 & 1.64 & -5.14 & $0.35 * * * *$ & $0.16^{*}$ & 0.62 & $0.22-0.53$ \\
\hline \multirow[t]{2}{*}{2015} & ATTC-2 & 30 & 4 & 2.64 & 2.14 & -3.64 & $0.001^{* *}$ & $0.36 * * * *$ & 0.00 & $0.23-0.89$ \\
\hline & AS2BH-4 & 20 & 4 & 4.39 & 3.59 & -4.90 & $0.23^{*}$ & $0.46 * * * *$ & 0.60 & $0.54-0.91$ \\
\hline
\end{tabular}

Significance at: ${ }^{*} p=0.01$ level; ${ }^{* *} p=0.001$ level; ${ }^{* * *} p=0.0001$ level; and ${ }^{* * * *} p=0.00001$ level.

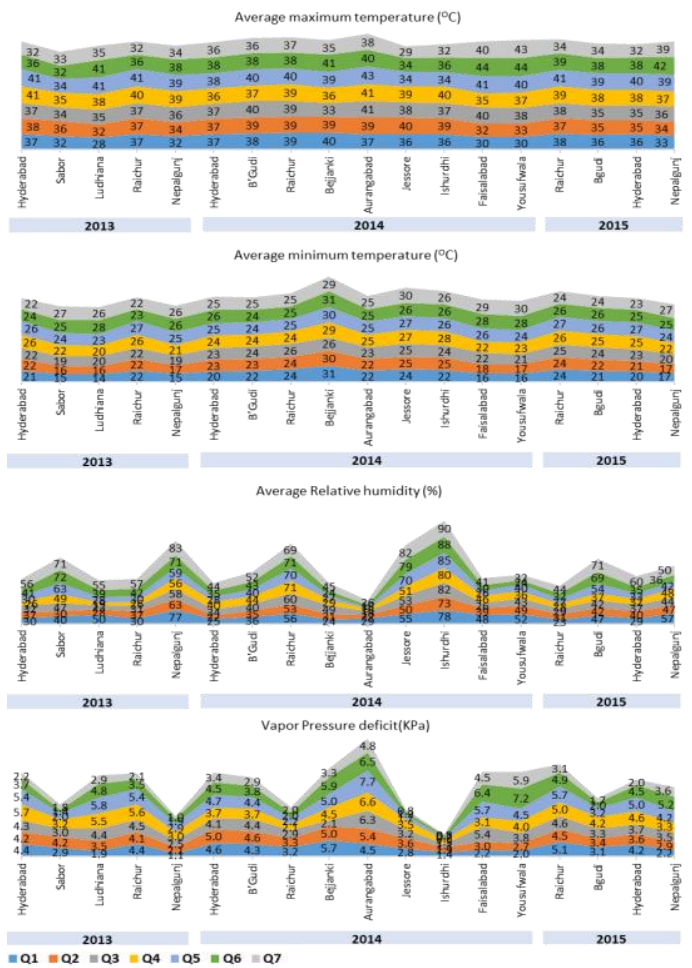

Fig 2. Average environmental variables across locations and fortnights (Q1 to Q7) of maize trials evaluated from 2013-2015. 
Table 3. Fortnightly average of different weather variables across different locations during 2013-2015.

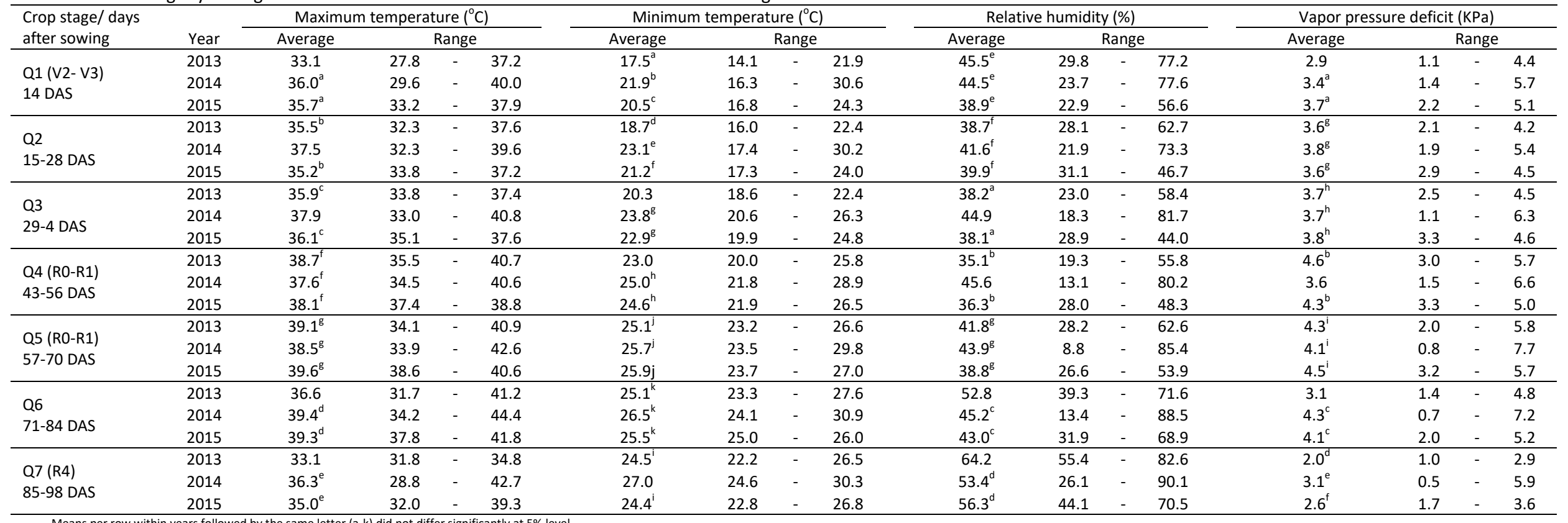

Means per row within years followed by the same letter (a-k) did not differ significantly at $5 \%$ level.

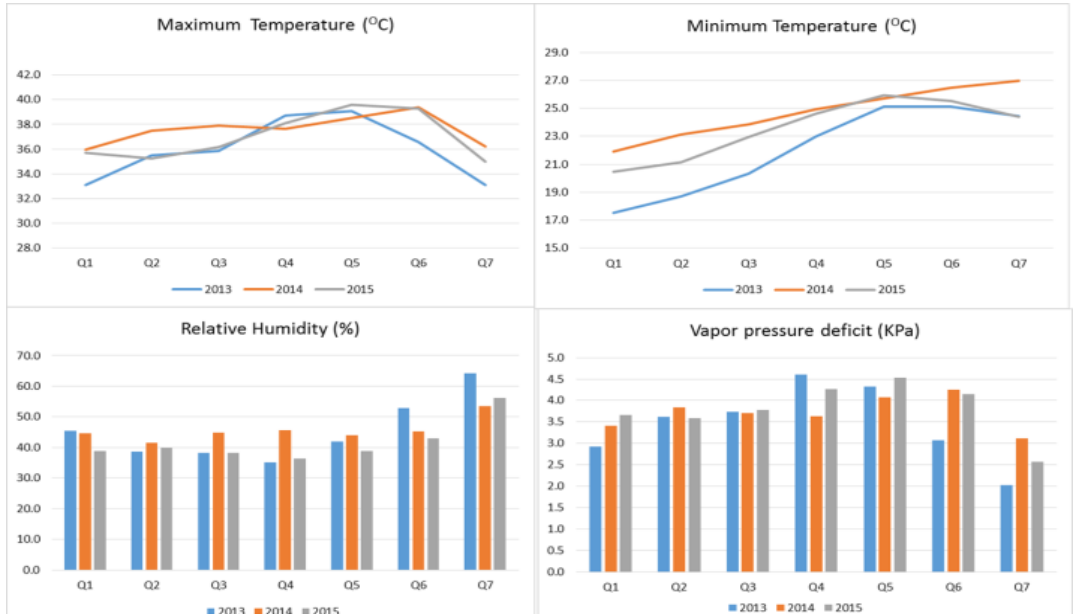

Fig 3. Average of environmental variables across seven fortnights during the maize growth season. 
Table 4. Variation (\%) explained by two PLS factors across trials during 2013 to 2015.

\begin{tabular}{cccc}
\hline Year & Trials & Factor 1 & Factor 2 \\
\hline \multirow{3}{*}{2013} & HTMAHT-1 & 19.80 & 13.41 \\
& HTMAHT-2 & 23.65 & 15.77 \\
& HSHT-1 & 20.96 & 10.44 \\
& ABHSHT-1 & 19.29 & 17.72 \\
& EWATC-1 & 21.86 & 16.79 \\
\multirow{2}{*}{2014} & EWATC-2 & 18.56 & 18.32 \\
& EYATC-2 & 23.19 & 7.01 \\
& EYBTC-1 & 23.43 & 16.49 \\
& EYBTC-2 & 21.23 & 13.33 \\
\multirow{2}{*}{2015} & ATTC-2 & 21.20 & 10.89 \\
& AS2BH-4 & 21.78 & 10.66 \\
\hline
\end{tabular}

Table 5. Range and rank of X-loadings from PLS factor 1 across 2013-2015 years with different environmental variables.

\begin{tabular}{|c|c|c|c|c|c|c|c|c|c|c|c|c|c|c|c|}
\hline \multirow{3}{*}{ Fortnight } & \multirow{3}{*}{$\begin{array}{l}\text { Days after sowing/ } \\
\text { crop Stage }\end{array}$} & \multirow{3}{*}{ Variables } & \multicolumn{9}{|c|}{ Range of absolute values of X-loadings by PLS factor 1 across trials } & \multirow{2}{*}{\multicolumn{4}{|c|}{ Rank of environmental variable }} \\
\hline & & & 2013 & & & 2014 & & & 2015 & & & & & & \\
\hline & & & Min & & Max & Min & & Max & Min & & Max & 2013 & 2014 & 2015 & Across \\
\hline \multirow{4}{*}{ Q1 } & \multirow{4}{*}{$14(\mathrm{~V} 2-\mathrm{V} 3)$} & Q1Max & 0.35 & - & 0.67 & 0.06 & - & 0.89 & 0.72 & & 0.73 & 18 & 28 & 1 & 13 \\
\hline & & Q1Min & 0.63 & - & 0.86 & 0.18 & - & 0.97 & 0.69 & & 0.7 & 8 & 17 & 7 & 5 \\
\hline & & Q1RH & 0.48 & - & 0.66 & 0.53 & - & 0.8 & 0.67 & & 0.68 & 17 & 9 & 12 & 8 \\
\hline & & Q1VPD & 0.55 & - & 0.79 & 0.24 & - & 0.82 & 0.7 & & 0.7 & 9 & 15 & 4 & 3 \\
\hline \multirow{4}{*}{ Q2 } & \multirow{4}{*}{28} & Q2Max & 0.19 & - & 0.57 & 0.15 & - & 0.81 & 0.67 & rat & 0.68 & 26 & 27 & 12 & 22 \\
\hline & & Q2Min & 0.68 & - & 0.89 & 0.11 & - & 0.99 & 0.69 & . & 0.71 & 4 & 21 & 6 & 4 \\
\hline & & Q2RH & 0.26 & - & 0.29 & 0.2 & - & 0.83 & 0.68 & & 0.7 & 28 & 11 & 8 & 13 \\
\hline & & Q2VPD & 0.36 & - & 0.53 & 0.16 & - & 0.72 & 0.68 & & 0.7 & 25 & 16 & 9 & 14 \\
\hline \multirow{3}{*}{ Q3 } & \multirow{3}{*}{42} & Q3Min & 0.8 & - & 0.94 & 0.1 & - & 0.92 & 0.65 & & 0.69 & 1 & 23 & 12 & 7 \\
\hline & & Q3RH & 0.57 & - & 0.7 & 0.51 & - & 0.81 & 0.63 & & 0.66 & 16 & 10 & 15 & 9 \\
\hline & & Q3VPD & 0.73 & - & 0.8 & 0.06 & - & 0.97 & 0.52 & & 0.57 & 6 & 19 & 17 & 10 \\
\hline \multirow{4}{*}{ Q4 } & \multirow{4}{*}{56 (R0-R1) } & Q4Max & 0.69 & - & 0.74 & 0.11 & - & 0.9 & 0.67 & & 0.68 & 10 & 7 & 11 & 3 \\
\hline & & Q4Min & 0.45 & - & 0.76 & 0.07 & - & 0.94 & 0.69 & & 0.72 & 14 & 25 & 5 & 11 \\
\hline & & Q4RH & 0.62 & - & 0.74 & 0.57 & - & 0.86 & 0.7 & & 0.73 & 15 & 4 & 3 & 2 \\
\hline & & Q4VPD & 0.75 & - & 0.83 & 0.41 & - & 0.94 & 0.71 & & 0.74 & 3 & 5 & 1 & 1 \\
\hline \multirow{3}{*}{ Q5 } & \multirow{3}{*}{70 (R0-R1) } & Q5Max & 0.54 & - & 0.68 & 0.33 & - & 0.96 & 0.38 & & 0.44 & 19 & 12 & 19 & 14 \\
\hline & & Q5Min & 0.36 & - & 0.63 & 0.1 & - & 0.68 & 0.66 & & 0.7 & 20 & 24 & 10 & 16 \\
\hline & & Q5RH & 0.7 & - & 0.82 & 0.08 & - & 0.92 & 0.36 & & 0.41 & 5 & 1 & 22 & 3 \\
\hline \multirow{3}{*}{ Q6 } & \multirow{3}{*}{84} & Q6Min & 0.27 & - & 0.61 & 0.23 & - & 0.74 & 0.35 & . & 0.35 & 22 & 18 & 23 & 21 \\
\hline & & Q6RH & 0.68 & - & 0.8 & 0.03 & - & 0.97 & 0.05 & . & 0.11 & 7 & 2 & 26 & 6 \\
\hline & & Q6VPD & 0.45 & - & 0.67 & 0.13 & - & 0.93 & 0.03 & & 0.11 & 21 & 6 & 26 & 15 \\
\hline \multirow{4}{*}{ Q7 } & \multirow{4}{*}{$98(R 4)$} & Q7Max & 0.26 & - & 0.6 & 0.24 & - & 0.85 & 0.53 & & 0.6 & 23 & 20 & 16 & 18 \\
\hline & & Q7Min & 0.74 & - & 0.9 & 0.04 & - & 0.71 & 0.46 & & 0.54 & 2 & 26 & 18 & 12 \\
\hline & & Q7RH & 0.66 & - & 0.72 & 0.14 & - & 0.96 & 0.04 & & 0.14 & 13 & 8 & 26 & 13 \\
\hline & & Q7VPD & 0.36 & - & 0.52 & 0.37 & - & 0.91 & 0.21 & & 0.31 & 24 & 14 & 24 & 20 \\
\hline
\end{tabular}

Max $=$ Maximum temperature $\left(T_{\max }\right)$, Min $=$ Minimum temperature $\left(T_{\min }\right), R H=$ Relative humidity, and $\mathrm{VPD}=$ Vapor Pressure Deficit. 
(Table 5). In general RH during the reproductive stage (Q4) had positive loadings; $\mathrm{T}_{\max }(\mathrm{Q} 1)$ and VPD (Q4) had negative loading. Across the years, vapor pressure deficit during the flowering stage (Q4) contributed substantially to GXE variation followed by relative humidity (Q4-Q5).

\section{Discussion}

Three-year trial dataset used in the current study represents the performance of hybrids during spring season across different locations of South Asia. These locations were largely characterized by high temperature throughout the trial season (Figure 3$)$. The low trial yield $(<4 \mathrm{t} / \mathrm{Ha})$ recorded across these test locations are probably a result of the heat stress $\left(T_{\max }>32^{\circ} \mathrm{C}\right)$ observed during the entire crop growth. Several studies have discussed the relation between temperature and maize growth and also defined the impact of temperature beyond a threshold. For instance, high temperatures $\left(>28^{\circ} \mathrm{C}\right)$ during initial stages effect the emergence of the crop, largely by impacting the rate of protein synthesis by maize embryos (Rilkey, 1981). During grain filling high temperatures $\left(>35^{\circ} \mathrm{C}\right)$ reduces kernel growth rate (Badu-Apraku et al. 1983, Jones et al. 1984; Commuri and Jones, 2001) and high temperature $\left(>35^{\circ} \mathrm{C}\right.$ ) during flowering stages impact pollen viability (Herrero and Johnson, 1980; Dupuis and Dumas, 1990). Among the different stages of crop growth flowering stage has been reported as the most critical to high temperature stress (Hatfield and Prueger, 2015). In the current study $T_{\max }$ during flowering is identified as one of the critical variable (though not the foremost) contributing to the yield variation observed in the spring season crop. The test locations in this study did not differ significantly for $\mathrm{T}_{\max }\left(>40^{\circ} \mathrm{C}\right)$ during flowering, and might be the reason of non-identification of this variable as the foremost component contributing to yield variation.

In the present study, $T_{\min }$ observed across locations followed a trend similar to $T_{\max }$. In the 2014 trialing season, $T_{\min }$ across locations recorded a gradual increase throughout the crop cycle. In the trialing seasons of 2013 and 2015, the locations sampled recorded a slight dip in this temperature during crop maturity. While there are no direct estimates of losses in corn yields due to increase in $\mathrm{T}_{\min }$, Hatfield et al. (2011) observed that the effects of minimum temperature $\left(>30^{\circ} \mathrm{C}\right)$ could potentially reduce biomass and crop yields by directly affecting the night time respiration rates of plants. In this study, however, we did not find a substantial effect of minimum temperature on grain yield variation as explained through PLS factor 1 for the germplasm studied, except in the 2013 trialing season, wherein $T_{\min }$ during the vegetative stage was found to be a major variable in the observed differential yield. The inability of the analysis to identify minimum temperature across years as an important variable might be because: (i) the effects of elevated minimum temperature are rather indirect and a result of a combination of other environmental variables or/and (ii) the environments sampled for the current study did not pose enough $\mathrm{T}_{\min }$ variation to be expressed in the observed yield losses.

Two other important environmental co-variables studied were average relative humidity and vapor pressure deficit. Average $\mathrm{RH}$ across all locations studied was at its peak during the crop maturing stage (Q7-Q8), while the VPD was highest during the crop flowering stage. Hence, the atmosphere was drier during anthesis (Q4-Q5 stage) while it was relatively more humid during the grain filling stage. All the other crop growth stages presented relatively stable environmental conditions across locations and years. The PLS analysis in the current study revealed VPD and $\mathrm{RH}$ at crop flowering stage to be the most important environmental variables contributing to observed yield variation. In maize, the advantage of a humid atmosphere over a drier one in terms of better water-use efficiency translating to higher dry matter production, and eventually higher yields, have been clearly demonstrated in a study by Ben-Asher et al. (2013). Further, it has also been reported that the effect of high temperature is enhanced under high VPD, because pollen viability (prior to silk reception) is a function of pollen moisture content that is strongly dependent on vapor pressure deficit (Fonseca and Westgate, 2005). The lower yield as observed in our trials and VPD and RH being identified as two major components particularly during the flowering stage of crop further corroborates these findings.

\section{Materials and Methods}

\section{Experimental datasets}

Three years of spring trial dataset were used for this study, and they constituted different trials involving early and advanced generation breeding germplasm screened for heat stress tolerance during the spring season across several locations of tropical South Asian countries - including India, Pakistan, Nepal and Bangladesh. All the trials were laid out following an alpha lattice design in 3 to $4 \mathrm{~m}$ two row plots at a spacing of $75 \mathrm{~cm} \times 20 \mathrm{~cm}$, to represent an optimum plant population size of 66,666 plants/ha. The locations and trial matrix are presented in Table 1 and detailed here.

\section{Year 2013 trialing season}

Phenotypes from three trials namely HSHT-1, HTMAHT-1 and HTMAHT-2 formed this year trial dataset. The trials were screened across six high temperature environments of South Asia. Trial HSHT-1 consists of experimental hybrids formed from selected maize hybrids with reasonable levels of heat tolerance. HTMAHT- 1 and HTMAHT- 2 trials constituted 300 test-crosses of elite breeding lines from International Maize and Wheat Improvement Centre (CIMMYT) -Asia program.

\section{Year 2014 trialing season}

A total of six trials were selected for this year dataset and consists of one advance generation (ABHSHT) single cross hybrid trial and five test-cross trials (EWATC-1 to EYBTC-2) constituting test crosses of $\mathrm{S}_{2: 3}$ families derived from six multiparent population. These trials were evaluated across 7-9 locations of South Asia during the spring season of 2014. 


\section{Year 2015 trialing season}

Two advanced generation trials, ATTC-2 and AS2BH-4, were used to form the 2015 dataset. While entries from ATTC-2 were planted in a single row (3-4 $\mathrm{m}$ ) two replication trials, entries of AS2BH-4 were replicated three times. The ATTC-2 trial was planted at five high temperature locations, while AS2BH4 trial was planted in four locations.

\section{Planting dataset}

Trials at each location were planted during the spring season, such that the window of vegetative to flowering stage of crop growth was exposed to high temperature regimes. As the last 5-10 years' weather data for the first fortnight of May revealed a period of high temperature $\left(\geq 40{ }^{\circ} \mathrm{C}\right)$ in most of the locations in South Asia, the planting of trials was done between the second fortnight of March to the first week of April across locations.

\section{Weather data}

Daily climate data on three environmental variables $-\mathrm{T}_{\max }$ and $\mathrm{T}_{\min }\left(\right.$ in ${ }^{\circ} \mathrm{C}$ ), and relative humidity (\%) was recorded from each of the locations during the crop cycle (from planting till harvest). The fourth variable, vapor pressure deficit, was calculated as the absolute difference between saturation vapor pressure and actual atmospheric vapor pressure using the following formula by Anderson, 1936.

$[0.6108 \times \exp [17.27 \times T /(T$

$$
\begin{aligned}
& +237.3)]]-[(R H / 100)(0.6108 \\
& \times \exp (17.27 * T /(T+237.3))]
\end{aligned}
$$

Where, $T$ represents the temperature (in ${ }^{\circ} \mathrm{C}$ ) and $\mathrm{RH}$ represents relative humidity $(\%)$.

\section{Data processing}

Phenotypic data recorded on the grain yield per plot was adjusted to 12.5 per cent moisture and scaled to tons/ha. Trials that exhibited less than 20 per cent heritability on single location analysis were dropped from further analysis (Table 1 ). In total, 11 trials evaluated across 12 locations over a period of three years (2013 to 2015) were selected for the current study. Daily weather data variables on four parameters $\left(T_{\max }, T_{\min }, R H\right.$ and VPD) based on each location trial were averaged for fortnightly (14 days) intervals from the date of planting (DAS) till around 98 days after planting, such that each fortnight represented a major crop growth stage starting from seedling emergence $\left(V_{E}\right)$ to dough stage $\left(R_{4}\right)$. The seven fortnights were then designated as Q1 to Q7. Hence, in total, 28 environmental variables spanning across seven fortnights of crop growth formed the basis for the partial least square analysis.

\section{Data analysis}

\section{Single and across site analysis}

The Residual Maximum likelihood (REML) approach was used to analyze grain yield from a single site trial dataset, treating blocks, entries and replications as random factors. Single location heritability of the trials was computed using the variance estimates and trials with poor repeatability $(<0.15)$ were dropped from further analysis (Table 1). Trials with good heritability were then subjected to across-location analysis and variance components estimated treating locations, entries, replication, and blocks as random effect. Data analysis was done using the R-software package ( $R$ development team, 2008) using the mixed model package Ime4 and the function Imer (linear mixed effect model) was used to fit the data. Broad-sense heritability across locations for grain yield was estimated from the variance components using the formula below:

Heritability (H2bs)

$$
\begin{aligned}
& =\sigma^{\wedge} 2 G /\left[\sigma^{\wedge} 2 G+\sigma^{\wedge} 2 G \times E / n L\right. \\
& \left.+\sigma^{\wedge} 2 E /[n R \times n L]\right]
\end{aligned}
$$

Wherein, $\sigma^{\wedge} 2 \mathrm{G}, \sigma^{\wedge} 2 \mathrm{G}_{\times} \mathrm{E}$ and $\sigma^{\wedge} 2 \mathrm{E}$ represent genotypic, genotype $\times$ environment and residual variance respectively, while $\mathrm{nL}$ and $\mathrm{nR}$ represent the number of locations and replications respectively.

\section{Partial least square analysis (PLS)}

PLS analysis was performed for individual trials using the yield dataset across locations for respective trials and the average of environmental variables across the seven fortnights (Q1-Q7) in the growing season. The data was analyzed using $R$ implemented through the software handle GEA-R (Genotype $\times$ Environment Analysis with $R$ for Windows) Version 2.0 (Pacheco et al. 2015). Plot data from each of the trial evaluated at different locations was used for the analysis. The data was analyzed following the model described by Vargas et al. (1998) wherein, the dependent variable (grain yield) was represented as a matrix of the number of genotypes $\times$ the number of locations where the trial was evaluated, while the environmental variables across the seven fortnights at all locations where the trials were evaluated formed the explanatory matrix.

Latent factors obtained through PLS account for the variations observed in the response variables. The absolute values of Xloadings obtained for each variable for the latent factor represents the relative importance of that variable in explaining the $\mathrm{G} \times \mathrm{E}$ interaction component.

As this study aimed at understanding the environmental covariables contributing to yield variation among different high temperature stress locations, by comparing the results from different trial datasets, the variables were initially ranked based on their relative importance for one factor within a trial using the absolute values of their loadings. The average of these ranks represented the relative importance of the environmental variable in contributing to yield variations across locations across years. The range of $\mathrm{X}$-loading and relative ranks of each variable across the year is presented in Table 4.

\section{Conclusion}

All the sites in the study, though characterized by their relative high maximum temperatures, varied largely in other 
environmental variables and could be further classified as dry and humid environments. Across locations and years, a consistently high X-loading was observed for $\mathrm{RH}$ and VPD, particularly during the flowering stage (Q4-Q5), implicating them as major determinants of yield variation across locations. These results did not indicate a major role for minimum temperature in contributing to $\mathrm{G} \times \mathrm{E}$, as the locations across the test sites did not vary substantially for the same; rather, VPD and $\mathrm{RH}$ at maximum temperature were found to be the key contributors to $G \times E$ effects, and therefore, yield variability across locations.

\section{Acknowledgements}

The authors are thankful to the researchers of national partners of India, Nepal, Bangladesh and Pakistan for the conduct of the experimental trials under the project "Heat Tolerant Maize for Asia" funded by USAID - Feed the Future initiative and to the CGIAR Research Program on Maize (CRPMAIZE).

\section{References}

Anderson DB (1936) Relative humidity or vapor pressure deficit. Ecol. 17(2):277-282

Badu-Apraku B, Hunter RB, Tollenaar M (1983) Effect of temperature during grain filling on whole plant and grain yield in maize (Zea mays L.). Can . Plant Sci. 63:357-363

Ben-Asher J, Garcia y Garcia A, Flitcroft I, Hoogenboom G (2013) Effect of atmospheric water vapor on photosynthesis, transpiration and canopy conductance: a case study in corn. Plant Soil Environ. 59(12):549-555

Commuri PD, Jones RD (2001) High temperatures during endosperm cell division in maize: a genotypic comparison under in vitro and field conditions. Crop Sci. 41:1122-1130

Dupuis L, Dumas C (1990) Influence of temperature stress on in-vitro fertilization and protein synthesis in maize (Zea mays L.) reproductive systems. Plant Physiol. 94:114-125.

Ehsani MR, Upadhyaya SK, Slaughter D (1999) A NIR technique for rapid determination of soil mineral nitrogen. Precision Agric. 1:217-234.

FAO (2016) FAOSTAT. Food and Agriculture Organization of the United Nations, Rome, Italy.

Fassio A, Cozzolino D (2003) Non-destructive prediction of chemical composition in sunflower seeds by near infrared spectroscopy. Ind Crop Prod. 20:321-329.

Fonseca AE, Westgate ME (2005) Relationship between desiccation and viability of maize pollen. Field Crops Res. 94:114-115.

Hansen PM, Schjoerring JK (2003) Reflectance measurement of canopy biomass and nitrogen status in wheat crops using normalized difference vegetation indices and partial least squares regression. Remote Sens Environ. 86:542-553.

Hatfield JL, Boote KJ, Kimball BA, Ziska LH, Izaurralde RC, Ort D, Thomson AM, Wolf D (2011) Climate Impacts on Agriculture: Implications for Crop Production. Agron J. 103(2):351-370.

Hatfield JL, Prueger JH (2015) Temperature extremes: Effect on Plant growth and Development. Weather Climate Extremes. 10:4-10.
Herrero MP, Johnson RR (1980) High temperature stress and pollen viability in maize. Crop Sci. 20:796-800.

Hu Q, Buyanovsky G (2003) Climate effects on corn yield in Missouri. J Appl Meteorol. 42:1626-1635.

Huang Z, Turner BJ, Dury SJ, Wallis IR, Foley WJ (2004) Estimating foliage nitrogen concentration from HYMAP data using continuum removal analysis. Remote Sens Environ. 93:18-29.

Jones RJ, Ouattar S, Crookston RK (1984) Thermal environment during endosperm cell division and grain filling in maize: effects on kernel growth and development in vitro. Crop Sci. 24:133-137.

Lobell DB, Schlenker W, Costa-Roberts J (2011) Climate trends and global crop production since 1980. Sci. 333:616-620.

Pacheco A, Vargas $M$, Alvarado $G$, Rodríguez $F$, López $M$, Crossa J, Burgueño J (2015) GEA-R (Genotype x Environment Analysis whit $R$ for Windows.) Version 2.0, URL http://hdl.handle.net/11529/10203 International Maize and Wheat Improvement Center.

R Development Core Team (2008) R: A language and environment for statistical computing. $R$ Foundation for Statistical Computing, Vienna, Austria. ISBN 3-900051-07-0, URL http://www.R-project.org

Rilkey GJP (1981) Effects of high temperature on protein synthesis during germination of maize (Zea mays L.). Planta. 151(1):75-80.

Talbot M, Wheelwright AV (1989) The analysis of genotype $\times$ environment interactions by partial least squares regression. Biuletyn Oceny Odmian, Zeszyt. 21/22:19-25.

Tobias RD (2003) An introduction to partial least squares regression. SAS Institute Inc., Cary, NC http://www.ats.ucla.edu/stat/sas/library/pls.pdf.

Vargas M, Crossa J, Reynolds MP, Dhungana P, Eskridge KM (2007) Structural equation modelling for studying genotype xenvironment interactions of physiological traits affecting yield in wheat. J Agricu Sci. 145:151-161.

Vargas M, Crossa J, Van Eeuwijk FA, Sayre KD, Reynolds PM (2001) Interpreting treatment $x$ environment interaction in agronomy trials. Agronomy J. 93:949-960.

Vargas M, Van Eeuwijk FA, Crossa J, Ribaut JM (2006) Mapping QTLs and QTL $\times$ environment interaction for CIMMYT maize drought stress program using factorial regression and partial least squares methods. Theor Appl Genet. 112:1009-1023.

Vargas M, Crossa J, Van Eeuwijk FA, Sayre KD, Reynolds PM, Ramirez ME, Talbot M (1998) Interpreting treatment $\times$ environment interaction in wheat using partial least square. Crop Sci. 38:679-689.

Westcott B (1986) Some methods of analyzing genotypeenvironment interaction. Hered. 56:243-253.

Zaidi PH, Cairns JE (2011) Enhancing climate-resilience in tropical maize. In: PH Zaidi et al. (Eds). Addressing climate change effects and meeting maize demand for Asia. Book of Extended Summaries of the 11th Asian Maze Conference, Nanning, China, 7-11 November 2011. 